\title{
European Passengers' Satisfaction And Fairness Perceptions About Turkish Airports
}

\author{
Nuriye Güreş, Mustafa Kemal University, Turkey \\ Halil Demirer, Mustafa Kemal University, Turkey \\ Mehmet Kara, Mustafa Kemal University, Turkey
}

\begin{abstract}
The purpose of this study is to find the relationship between personal and flight characteristics of European passengers' satisfaction and fairness perceptions about Turkish airports. The hypotheses were tested on a sample of 559 European passengers in Turkish Airports. Respondents voluntarily participated to the survey. Self reported questionnaire forms were filled in by the passengers waiting in the international area of the airports in a face to face interview manner. To analyze the collected data, independent sample of t-test and one-way analysis of variance (ANOVA) were used. Study results indicated that the less flying passengers are more satisfied about Turkish airports than the more flying passengers. Also, passengers travelling for tourism purpose have the highest fairness perception about the services delivered in Turkish airports. But, the services of Turkish airports are perceived relatively less fair by the passengers travelling for health purposes. The most fairly perceiving passengers are of middle income level.
\end{abstract}

Keywords: Passenger satisfaction, fairness perception, Turkish airports

\section{INTRODUCTION}

$\mathrm{n}$ recent years in Turkey, the number of private airline companies which transport passengers with airline and fleet has increased, so ticket prices have decreased. Therefore, travellers have given preference to air transportation more than before. Nevertheless, increasing trade and tourism activities and government promotion for civil air transportation show that rational proportion of airline passengers' transportation in Turkey will increase. In order to evaluate this potential effectively, the airports have an strategic importance.

Flight is an integrated service with airport which is static element and airplane which is a dynamic element. In this study, excluding the airplanes and airlines as dynamic elements, only airports which have a national value and importance for country image have been included and searched.

Especially after 9/11 attacts, airport security have come into prominence in the whole world . So providing airport security and thereby customer satisfaction have become compulsory for the countries' civil aviation management.

Modern business approach requires focusing on customers . Also in air passenger transportation, acting upon the thought of service with customer orientation, passengers'ideas and attitutes towards airports' services have become extremely important. Therefore, passengers who travel with airways have been examined in this research.

Furthermore, while many researches have been made about airline companies which have intensive competition, researches about airports are relatively less. At the same time, while the topics as customer satisfaction, safety and equality in service have precedence in researches related to airline companies, airports have been neglected in this manner or the problems have not been dealed with customer orientation in researches. So in 
this study, European passengers' satisfaction and their fairness perceptions about Turkish airports have been searched.

\section{THEORETICAL BACKGROUND}

\section{Passenger Satisfaction At Airport}

Customer satisfaction is a wide assesment based on total purchase and consumption experience in time related to a good or service (Anderson and others, 1994). Customer satisfaction is the result of comparison between expectancies and the perceived performans of consumers' relevant aspects in all stages of the consumption experience (Bassi and Guido, 2006).

Determining customer satisfaction has an important role in distributing the services effectively. Having knowledge with the level of customer satisfaction and using this knowledge in application provide the managers competitive advantage as the result of product differentiation, keeping customers and positive word of mouth communication (Yüksel and Rimmington, 1998).

Paternoster states that excellent customer service is the synergy created when an airport's ability to exceed its customers' needs and expectations consistently matches its customers' perception that their needs and expectations are well met. Also if airport management takes a strategic and holistic approach to customer service and aiport branding, customer satisfaction with the airport experience can be significantly improved and aiport net revenues can be tracked to show a direct relationship with increased customer satisfaction (2008: 218). So passengers' satisfaction about the airports is very important for airport managements.

In previous literature, Nebeker and his friends (2001) examined whether employee satisfaction is linked to organizational performance and customer satisfaction. Satisfaction data from 12842 employees at 60 airport stations and performance data of those stations were used to explore the relationship between satisfaction levels and airpor station performance. Results indicated that traffic volume and some dimensions of employee satisfaction are related to the performance. In addition, employee affective commitment and airport traffic volume interact in accounting for customer satisfaction.

Gritza and friends (2006) tried to uncover factors that determine passenger satisfaction at security screening points. Their findings showed that wait times at security screening points were significant determinants of passenger satisfaction. Moreover, according to the results the determinants of customer satisfaction were not stable over time and there were many other factors come into play. They suggest that further refinements in airport screening procedures should give careful consideration to the factors underlying passenger satisfaction and wait times should be minimized.

Martin - Cejas (2006) searched the relationship between passenger satisfaction and the level of service established in a check-in service at Canaria airport through a linear programming model. Research results showed that average waiting time and crowding level for airport facilities are two relevant aspects in quality perception and satisfaction of passengers. For regular flights, Canaria airport showed an excellent check-in facility service level, however for charter flights the level of service has to be improved.

Correia and Wirasinghe (2007) conducted a passenger survey at Sao Paulo International Airport in Brazil.They used qualitative survey data and derived quantitative values for passenger perceptions of service. At the end of the study, processing time, waiting time and space available per person have been determined as the main elements of service level given at the airport.

\section{Fairness Perception of Passengers}

Justice theory constitutes a basis for fairness in human social interactions both for exchange and workplace environment. Justice theory have three types of justice as distributive, procedural and interactional. Theory having four types of justice explains workplace fairness mostly by distributive justice. But in exchange environments as 
customer's service experience generally the interpersonal and informational justice types are found appropriate. Fairness in this study was located from this point of view. This point of view has its basis in the intersection of social psychological and marketing literature.

Sindhav and others (2006) researched the effects of fairness perception on passenger satisfaction in airports. The results of their study indicated that fairness perception has significant effects on passenger satisfaction. Besides, contradicting to previous research findings that the fairness perception on procedures had the largest effect on passenger satisfaction. Discrimination in the delivery of the airport service is not appreciated. This took place in the report about the airports in which discrimination among passengers on security procedures regarding their ethnicity, nationality and religious roots.

Many researchers have found that fairness influence satisfaction (Austin, McGinn, and Susmilch 1980; Goodwin and Ross 1992; Messick and Sentis 1983; Oliver 1997; Swan and Oliver, 1991; Szymanski and Henard 2001; Yoda, 2007). Thus any parameters effecting fairness perception would automatically have effect in the changes in passenger satisfaction as well. That is why in this study these two constructs were both taken into consideration.

The characteristics of passengers that may be responsible for the changes in fairness perception as well as passenger satisfaction were various.

\section{RESEARCH QUESTIONS AND HYPOTHESES}

Study has been designed on between-group comparisons in one time measurement in the field. Research model has included passenger satisfaction and fairness perception as the dependent and the personal and flight characteristics as independent variables of the study. Thus six main research questions given below have been produced:

- $\quad$ Are there any relationships between educational level of passengers and their satisfaction and fairness perceptions about Turkish airports?

- $\quad$ Are there any relationships between gender and their satisfaction and fairness perceptions about Turkish airports?

- $\quad$ Are there any relationships between age and their satisfaction and fairness perceptions about Turkish airports?

- $\quad$ Are there any relationships between average monthly income level and their satisfaction and fairness perceptions about Turkish airports?

- $\quad$ Are there any relationships between flight frequency in a year and their satisfaction and fairness perceptions about Turkish airports?

- $\quad$ Are there any relationships between flight objective and their satisfaction and fairness perceptions about Turkish airports?

Six hypotheses denoting that satisfaction and fairness perceptions have meaningful relationship with educational level, gender, age, average monthly income level, flight frequency in a year and flight objectives of passengers about Turkish airports.

$\mathbf{H}_{1}=\quad$ There is a meaningful relationship between educational level and passenger satisfaction and fairness perceptions about Turkish airports.

$\mathbf{H}_{2}=\quad$ There is a meaningful relationship between gender and passenger satisfaction and fairness perceptions about Turkish airports.

$\mathbf{H}_{3}=\quad$ There is a meaningful relationship between age and passenger satisfaction and fairness perceptions about Turkish airports.

$\mathbf{H}_{4}=\quad$ There is a meaningful relationship between average monthly income level and passenger satisfaction and fairness perceptions about Turkish airports.

$\mathbf{H}_{5}=\quad$ There is a meaningful relationship between flight frequency in a year and passenger satisfaction and fairness perceptions about Turkish airports. 
$\mathbf{H}_{\mathbf{6}}=\quad$ There is a meaningful relationship between flight objective and passenger satisfaction and fairness perceptions about Turkish airports.

Research model proposed in the study can be illustrated as in the Figure 1.

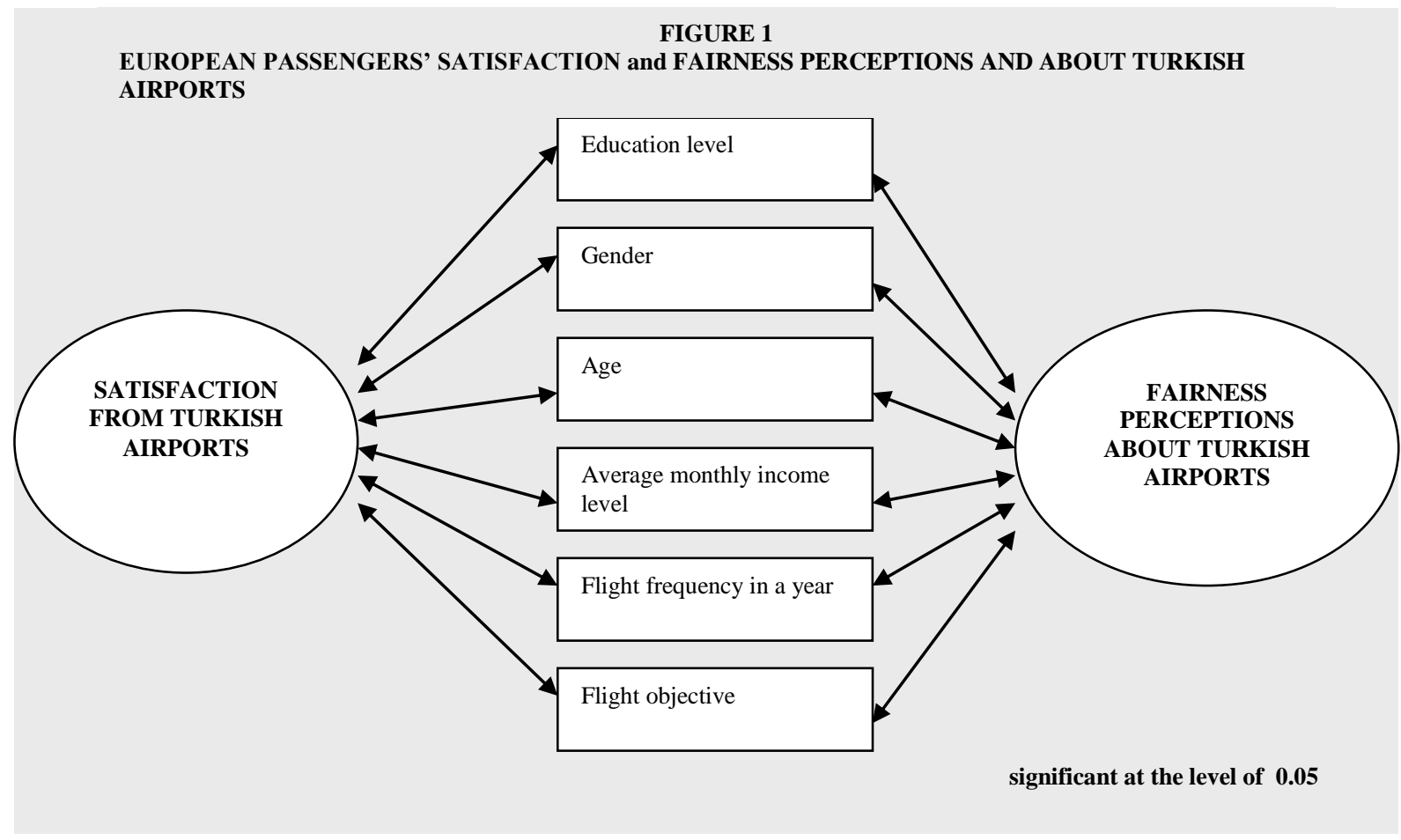

III. METHOD

\section{Sample}

Tourism statistics regarding nationalities provided by Turkish Statistical Institute (TUIK) were taken as the basis for the population of the survey. The distribution of 10 million European passengers regarding nationalities in percentages were as follows: Germany $\% 39$, England $\% 12$, Netherland $\% 12$, France $\%$, Austria $\% 4$, Belgium $\%$ 4, Sweden \% 4, Denmark \% 2, Italy \% 2, Poland \% 1, Spain \% 0.8, Finland \% 0.4, Greece \% 0.4, Ireland \% 0.2. These proportions were taken into consideration in sampling phase of the study.

The hypotheses were tested on a sample of 559 European passengers in Turkish Airports. Respondents voluntarily participated to the survey. Self reported questionnaire forms were filled in by the passengers waiting in the international area of the airports in a face to face interview manner.

\section{Measures}

The scales used in the survey were translated into three European languages as English, German and French. In order to test the reliability of the scales, 80 filled forms were used for pilot study to test the scales that will be included in the survey.

The criterion developed by Airport Council International (ACI) to evaluate the overall satisfaction about the services in the airport was totally adopted to the survey. ACI Europe has been founded by 45 countries that have 450 airport. It has the authority to represent nearly the $90 \%$ of the European air traffic. The form called as Airport 
Voluntary Commitment on Air Passenger Service is a 14 item scale included statements such as "This airport does not meet needs of disabled or older passengers." The scale in total had an appropriate value of cronbach alpha $(\alpha=.85)$ and was fonud to be reliable (Nunnally, 1978).

Fairness perceptions of air passengers was meausured using the scale $(\alpha=.81)$ developed by Colquitt (2001) and tested by Sindhav (2006). The scale consists 15 items. One of the items was as "Security operations are carried out equally at this airport." All of the statements were scaled as $(1=$ strongly disagree $) .. .(7=$ strongly agree $)$.

Finally the personal profile and flight experiences of the passengers were surveyed.

\section{Procedure}

There are two tourism seasons as high and low having reflection on airports as high and low passenger traffic. Sampling was executed in two phases regarding this perspective. Moreover two additional phases were include as weekdays and weekends to insure the heterogeinty in the sample. The international fields in the airports were used to have the questionnaires filled in a convenience manner. When invalid forms were subtracted by assessing the missing values in the forms, total number valid forms decreased to 559. Data collecting method used in the study was self-report questionnaires filled by the respondents. Research model included satisfaction and fairness perceptions of passengers about airport services and applications as dependent variables of the study. Independent variables of the study were education level, gender, age, average monthly income, flight frequency in a year, flight objective. T-test and ANOVA techniques were used to examine the differences among comparison groups of passengers.

\section{RESULTS}

The main assumption of the literature that passenger satisfaction and fairness perception has correlation was tested by pearson two tailed correlation coefficient $(\mathrm{p}=0,58)$ at 0.01 significance level.

The hypothesis on flight frequency has been tested by using independent sample of t-test. On the other hand, the hypotheses on flight objective and monthly average income was tested by using one-way analysis of variance (ANOVA).

A. Flight Frequency on Satisfaction and Fairness Perceptions of European Passengers about Turkish Airports

Table-1. Flight Frequency on Satisfaction and Fairness Perceptions

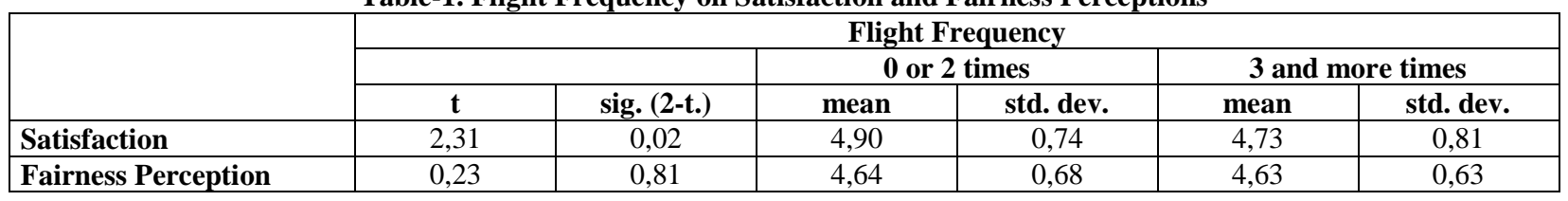

Table-1. indicates that there is a significant difference between the means of less and more frequently flying passengers regarding satisfaction about Turkish airports $(\mathrm{p}<0,05)$. It is evident from the means of the groups that the passengers with low flying records are more satisfied about Turkish airports than the passengers with high flying records. But the difference for fairness perceptions is not significant between groups $(\mathrm{p} \geq 0,05)$.

B. Flight Objective on Satisfaction and Fairness Perceptions of European Passengers about Turkish Airports

Table-2. indicates that there is a significant difference among five groups of passengers with different flight objectives regarding fairness perception $(\mathrm{p}<0,05)$. But the difference for satisfacton is not significant among groups $(\mathrm{p} \geq 0,05)$. 
Table-2. Flight Objective on Satisfaction and Fairness Perceptions

\begin{tabular}{|c|c|c|c|c|}
\hline \multicolumn{5}{|c|}{ ANOVA } \\
\hline & & mean & $\mathbf{F}$ & Sig. \\
\hline \multirow[t]{5}{*}{ Satisfaction } & Business & 4,82 & \multirow{5}{*}{1,67} & \multirow{5}{*}{0,15} \\
\hline & Education & 4,69 & & \\
\hline & Tourism & 4,81 & & \\
\hline & Health & 4,33 & & \\
\hline & & & & \\
\hline \multirow[t]{5}{*}{ Fairness Perception } & Business & 4,62 & \multirow[b]{5}{*}{4,97} & \multirow[b]{5}{*}{0,00} \\
\hline & Education & 4,24 & & \\
\hline & Tourism & 4,65 & & \\
\hline & Health & 3,99 & & \\
\hline & & & & \\
\hline
\end{tabular}

Table-3. Multiple Comparisons

\begin{tabular}{|c|c|c|c|}
\hline \multicolumn{2}{|c|}{ Multiple Comparisons } & \multicolumn{2}{c|}{ Post Hoc (Games-Howell) } \\
\hline Dependent variable & (I) class & Sig. \\
\hline Fairness perception & Health & Business & 0,00 \\
\cline { 3 - 4 } & & Tourism & 0,00 \\
\hline
\end{tabular}

Table-3. shows that there is a significant difference between health group and business group, health group and tourism group regarding fairness perception. Passengers travelling for tourism purposes are the group that has the most positive fairness perception scores. Whereas passengers travelling for health purposes are the group that has the most negative fairness perception scores.

C. Monthly Average Income on Satisfaction and Fairness Perceptions of European Passengers about Turkish Airports

Table-4. Monthly Average Income on Satisfaction and Fairness Perceptions

\begin{tabular}{|c|c|c|c|c|}
\hline \multicolumn{5}{|c|}{ ANOVA } \\
\hline & & mean & $\mathbf{F}$ & Sig. \\
\hline \multirow[t]{4}{*}{ Satisfaction } & Low level & 4,92 & \multirow[b]{4}{*}{2,80} & \multirow[b]{4}{*}{0,06} \\
\hline & Middle level & 5,12 & & \\
\hline & High level & 4,87 & & \\
\hline & & & & \\
\hline \multirow[t]{4}{*}{ Fairness Perception } & Low level & 4,65 & \multirow[b]{4}{*}{5,41} & \multirow[b]{4}{*}{0,00} \\
\hline & Middle level & 4,95 & & \\
\hline & High level & 4,66 & & \\
\hline & & & & \\
\hline
\end{tabular}

Table-4. indicates that there is a significant difference among three groups of passengers with different average monthly income regarding fairness perception $(\mathrm{p}<0,05)$. But the difference for satisfacton is not significant among groups $(\mathrm{p} \geq 0,05)$.

Table-5. Multiple Comparisons

\begin{tabular}{|c|c|c|c|}
\hline \multicolumn{2}{|c|}{ Multiple Comparisons } & Post Hoc (Games-Howell) \\
\hline Dependent variable & (I) class & Low level & Sig. \\
\hline Fairness perception & Middle level & High level & 0,01 \\
\cline { 3 - 4 } & & 0,01 & \\
\hline
\end{tabular}


Table-5. shows that there is a significant difference between middle and low income level, middle and high income level passengers regarding fairness perception. Middle income level group has the most positive fairness perception scores. Whereas low income level group has the most negative fairness perception scores.

Gender, educational level and age categories were the variables that indicated no meaningful association with passenger satisfaction and fairness perception in Turkish airports at significant level 0.05 .

Results of analyses removed the independent variables that have no effects from the model. The modified final model is illustrated in Figure 2.

FIGURE 2

EUROPEAN PASSENGERS' SATISFACTION and FAIRNESS PERCEPTIONS AND ABOUT TURKISH AIRPORTS

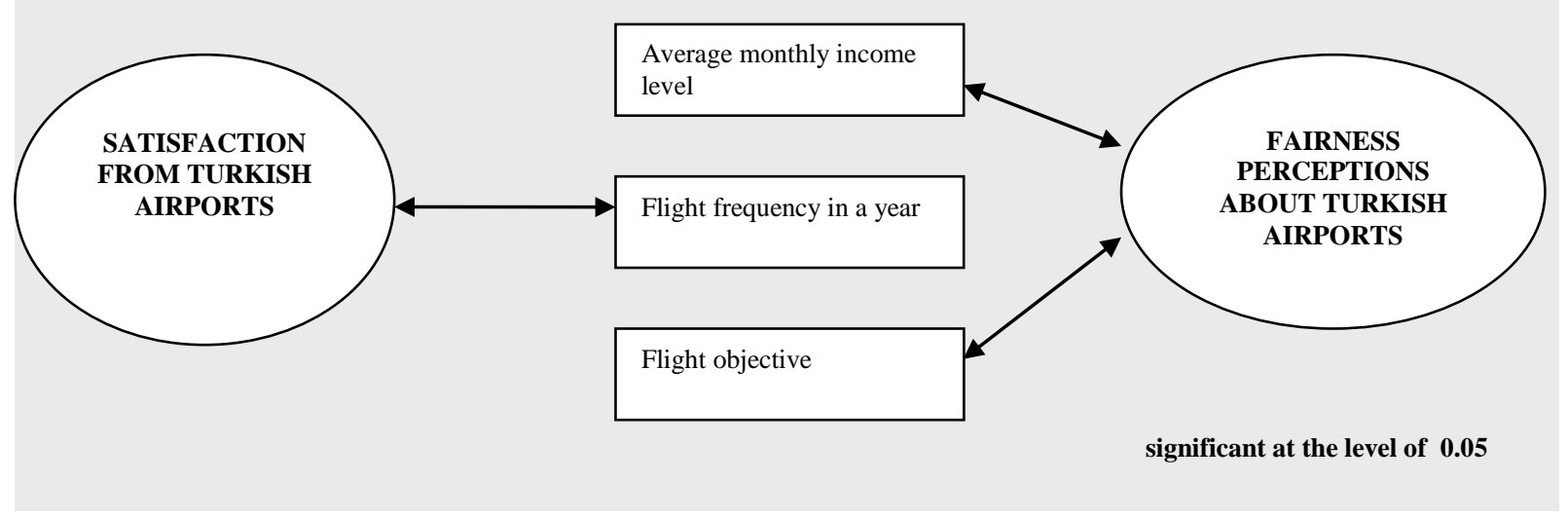

\section{DISCUSSIONS}

Firstly, the evidences indicating that the less flying passengers are more satisfied about Turkish airports than the more flying passengers assured our research expectations. This finding supports the literature that the higher the frequency of service encounter the less the satisfaction. This in part due to that more flight experience results in more expectation.

Secondly, statistical analyses showed that passengers travelling for tourism purpose have the highest fairness perception about the services delivered in Turkish airports. But, the services of Turkish airports are perceived relatively less fair by the passengers travelling for health purposes. This indicates that health travellers need to be treated kindly and more carefully. Services may be designed in a diffentiated mode for health travellers. This may be due to their sensitive psychology in that they are in need of a medical care.

Thirdly, middle income level passengers are those who perceive the services in Turkish airports the most fairly. Whereas the services in Turkish airports are perceived less fairly by passengers who are in low or high income levels.

As may be expressed in other words for European passengers at Turkish airports, flight frequency has relationship with passenger satisfaction but not with fairness perception. On the other side, monthly income level and flight objective have relationship with fairness perception but not with passenger satisfaction.

Due to European passengers constitute the majority of air passengers in Turkey, the detailed information about their satisfaction and fairness perceptions about the services in Turkish airports are very important. In the 
process of accession to European Union membership of Turkey, findings of this study could contribute to Turkish Civil Aviation Authorities to determine new measures to improve the quality of services in Turkish airports.

\section{AUTHOR INFORMATION}

Halil Demirer (PhD) Asst. Prof., School of Civil Aviation Mustafa Kemal University, Hatay/Turkey. Head of the Department of Air Transportation Management, Director of the School of Civil Aviation in Mustafa Kemal University.

Research interests include: Equal Opportunities, Equality Perceptions, and Values in The Organizations.

Memberships include: European Academy of Management membership and European Institute of Advanced Studies in Management.

Academic field: Business Management, Organizational Behavior

Mehmet Kara (PhD), Asst. Prof., School of Civil Aviation, Mustafa Kemal University, Hatay/Turkey. Vice Director of the School of Civil Aviation in Mustafa Kemal University.

Research interests: International Trade, Macro Economics

Memberships include: Istanbul Association of Economists

Academic field: Economics, Logistics

Nuriye Güreș $(\mathrm{PhD})$, School of Civil Aviation, Mustafa Kemal University, Hatay/Turkey. Erasmus Coordinator of the School of Civil Aviation in Mustafa Kemal University.

Research interests include: Services Marketing, Customer perceptions

Memberships include: American Marketing Association

Academic field: Marketing Management, Customer Relationship Management

\section{REFERENCES}

1. Airport Voluntary Commitment on Air Passenger Service http://www.aci-europe.org, (Reached date: 01.09.2007)

2. Anderson, E. W., Fornell, C., and Lehrmann, D. R. (1994). "Customer satisfaction, market share and profitability: Findings from Sweden,” Journal of Marketing, 58(3): 53-66.

3. Austin, W., McGinn, N.C. and Susmilch, C. (1980). "Internal standards revisited: Effects of social comparisons and expectancies on judgments of fairness and satisfaction," Journal of Experimental Social Psychology, 16.

4. Bassi, F., and Guido, G. (2006). "Measuring customer satisfaction: From product performance to consumption experience," Journal of Consumer Satisfaction, Dissatisfaction and Complaining Behavior, 19, 76-88.

5. Colquitt, J. A. (2001). "On the dimensionality of organizational justice: A construct validation of a measure," Journal of Applied Psychology, 86: 386-400.

6. Correia, A. R. and S. C. Wirasinghe. (2007). "Development of level of service standards for airport facilities: Application to Sao Paulo international airport," Journal of Air Transport Management, 13: 97 103.

7. Gkritza, K., D. Niemeier, Mannering, F.L. (2006). "Airport security screening and changing passenger satisfaction: An exploratory assessment." Journal of Air Transport Management, 12: 213-219. 
8. Goodwin, C. and Ross, I. (1992). "Consumer responses to service failure: Influence of procedural and interactional fairness perception," Journal of Business Research, 25: 149-163.

9. Martin-Cejas, R. R. (2006). "Tourism service quality begins at the airport," Tourism Management, 27: 874877.

10. Messick, D.M. and Sentis K. (1983). "Fairness, preference, and fairness biases," in Equity Theory, eds. David M. Messick and Karen S. Cook, New York: Praeger, 61-94.

11. Nebeker, D., L. Busso, et al. (2001). "Airline station performance as a function of employee satisfaction," Journal of Quality Management, 6: 29-45.

12. Oliver, R.L. (1997). Satisfaction: A behavioral perspective on the consumer, New York: McGraw-Hill.

13. Paternoster, J. (2008). "Excellent airport customer service meets successful branding strategy," Airport Management, 2(3), 218-226.

14. Sindhav, B., J. Holland, et al. (2006). "The impact of perceived fairness on satisfaction: Are airport security measures fair? Does it matter?" Journal of Marketing Theory and Practice, 14(4): 323-334.

15. Swan, J.E. and Oliver, R.L. (1991). "An applied analysis of buyer equity perceptions and satisfaction with automobile salespeople," Journal of Personal Selling and Sales Management, 11: 15-26.

16. Szymanski, D.M., and Henard, D.H. (2001). "Customer satisfaction: A meta-analysis of the empirical evidence," Journal of the Academy of Marketing Science, 29: 16-35.

17. Yoda, Takuro (2007). "Effect of unfairness on customer satisfaction: New insights into customer retention." Innovative Marketing, 3 (1): 44-55.

18. Yuksel, A., and Rimmington, M. (1998). "Customer-Satisfaction measurement: Performance Counts," Cornell Hotel and Restaurant Administration Quarterly, 39(6): 60-70. 


\section{NOTES}

